\title{
Film as medium for meaning making: A practical theological reflection
}

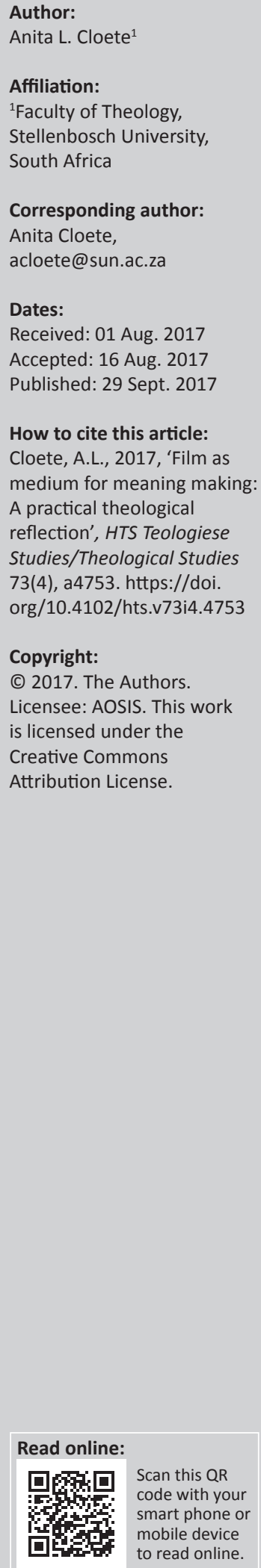

The reflection on film will be situated within the framework of popular culture and lived religion as recognised themes within the discipline of practical theology. It is argued that the perspective of viewers is of importance within the process of meaning-making. By focusing on the experience and meaning-making through the act of film-watching the emphasis is not so much on the message that the producer wishes to convey but rather on the experience that is created within the viewer. Experience is not viewed as only emotional, but rather that, at least, both the cognitive and emotional are key in the act of watching a film. It is therefore argued that this experience that is seldom reflected on by viewers could serve as a fruitful platform for meaning-making by the viewer. In a context where there seems to be a decline in institutionalised forms of religion, it is important to investigate emerging forms of religion. Furthermore, the turn to the self also makes people's experiences and practices in everyday life valuable resources for theological reflection. This reflection could provide a theoretical framework for especially empirical research on how film as specific form of media serves as a religious resource and plays a role in the construction of meaning and religious identity.

\section{Introduction}

Both religion and film as part of culture reflect the values, dreams and hopes of societies. Film specifically, is a powerful medium that conveys the values and beliefs of contemporary societies. The content of film and what the producers have in mind, however, is only one side of the coin, while what the audience makes of it is the other side. It is therefore argued that the act of filmwatching could create religious experience within the viewer. The focus will not be on the content of films or on religious film as such, but on film in general and it's potential to serve as religious source and the ability to create religious experience.

Summarised, the focus will be on how digital media enables religious identity formation and meaning making. The argument that the experience of the viewer is important built on the assumption that meaning is not constructed by the originator, but rather through negotiation between text, the receiver and the site of reception. In other words, in a media age, there seems to be a move from controlled messages to negotiated meaning-making processes by users and the producers of media. The first part of the article plots film as cultural product within the framework of popular culture and lived religion, followed by a discussion on the relationships between religion and film. The remainder of the article focuses on motivating the importance of theological reflection on the experience that could be created through the act film-watching.

\section{Film as cultural product}

As a cultural product and medium, film could be viewed as an important medium for meaningmaking. Cinema and film are embedded within culture and therefore a complex and interesting relationship exists between film, culture, ideology and the audience. Film is regarded as art that is pervasive and powerful, while film stars are often seen as 'cultural icons' (Browne 1997:9). Corrigan and White (2004) corroborate, describing film is a work of art, richly layered with cultural practices. This form of art is further described as creative and hybrid embedded in a matrix that move between 'realism' and 'fantasy'; 'art' and 'entertainment'.

Film combines three powerful elements, namely image, story and sound to give context and meaning to the story being told. Film tells us stories about themes of everyday experiences like love, hope, death, good, evil, violence and peace. Therefore, film is attractive to people of different age groups, because it tells stories with which we could associate. Largely it also tells our personal stories, that of the community and the world we are living in. In the words of Browne (1997:10) cinemas '... reproduce images that represent the world in which we live ... capture life and 'freeze' 
it for posterity'. Narratives have a very important social and cultural function and also provide an important link between theology and film. Film takes viewers on a journey, where the narrative is the 'engine' that drives it (Browne 1997:16).

Through the creative combination of music, sound, images and a text, film communicates with the audience. All these different elements are experienced at once and are communicating the (a) story. One of the important and outstanding features of film is the possible experience it could create. Watching a film therefore, calls on the viewer's imagination to participate in what he or she is seeing, hearing and feeling. Watching film draws people temporarily into an alternative world. Therefore film is so much more than just a cognitive exercise, because it has the potential of creating an experience from which meaning-making could be part of. Although watching film is associated with leisure time whereto it is assumed that people can escape to experience pleasure and be playful, it is also considered to be productive time where information could be gathered and interpreted. The combination of entertainment and serious life issues is therefore an interesting characteristic of film.

\section{Film as popular culture and lived religion}

I found it fit to plot the theological reflections on film as a site of meaning-making within the framework of popular culture and lived religion. According to Ganzevoort (2011:99) popular culture is the air we breathe, emphasising the regular basis we encounter expressions of popular culture. Both popular culture and lived religion are difficult to define and therefore I will attempt to give at least working definitions of these central concepts. Gordon Lynch (2005) connects popular culture with folk culture and mass culture. Although he uses these concepts interchangeable, he also refers to Fiske (1989) that contrasts these concepts; mass culture being a cultural system of producing products that will be available to mass populations. Popular culture, on the other hand, is what people do with these entertainments and commodities in real live which has little to do with the meanings that the producers have in mind.

Another definition of popular culture from Hall (1981) is also of importance because it enhances the possible meaning of the concepts and its application in everyday living. According to Hall (1981), popular culture is not simply what is popular with the masses, but should rather be understood as, on the one hand, the attempts of the elite to dominate and shape the culture of the mass classes, and on the other hand those that are excluded from this elite culture attempt to resist it. One group uses popular culture to control and shape culture and others use the same items, images and practices to resist the dominant ideas and values.

Another connection Lynch (2005:13) makes is the one between popular culture and everyday living. Different definitions of popular culture are '.. bound up with it meant to live and ordinary day-to-day life in a particular social and culture context' (Lynch 2005:14). According to Lynch (2005:15), these complexities with defining popular culture and everyday living could have certain benefits for our academic work. If we view popular culture as the sources, practices and shared environments of everyday life, it offers us a broader understanding of popular culture than what is often evident in scientific studies. In line with this broader understanding of popular culture, Lynch (2005:15) advocates a move from a documentary approach which focuses on artefacts and the text of a particular context, to a cultural approach that focuses on culture as a 'way of life'. This broader understanding of popular culture could lead to investigations that are wider than just text and artefacts because it offers a more open definition of popular culture and its religious significance (Lynch 2005:17). In this paper, I am opting for the Lynch (2008:73) definition of popular culture as '... the resources and practices of everyday life'.

Lived religion, on the other hand, is here understood as those everyday actions of people that have religious significance, although these actions may not be overtly religious. In the words of Ganzevoort and Roeland (2014:93): 'The concept of praxis and lived religion focus on what people do rather than 'official' religion, its sacred sources, its institutes and its doctrines'. Ganzevoort and Roeland (2014:94) point out that leisure activities (like watching film) may not be seen as religious actions, but could have religious significance for the people. These everyday actions, therefore, extend beyond the boundaries of institutional religion, but have an impact on how people interpret life and their relationship with the divine. It is argued in this article that watching film is one of these every day practices many people do repeatedly which are not viewed as a religious activity, but could have religious and moral significance.

Several researchers (Apostolides \& Meylahn 2014; Ganzevoort 2011, 2015; Priner 2009) argue that popular culture in the form of film is a sphere where a resurgence of religion is most evident. Of particular interest is the fact that the form of religion that surfaces in the media is not necessarily the same kind or form of traditional and institutional religion. Moreover, the setting where religion function in the media is outside the traditional and institutional setting of religious practices. In other words, a non-religious context (Ganzevoort 2011:97). Lived religion could, therefore, be viewed as those practices that are disembedded or outside the traditional religious setting like a church, but have religious significance. In Ganzevoorts' (2011) definition of popular culture the connection between popular culture and lived religion becomes more evident. 'The term 'popular culture' focuses on the common life as opposed to elite art... In terms of religion, it focuses on lived religion as the religious phenomena of ordinary life ...' (Ganzevoort 2011:99).

Lynch (2008:73) however, warns against a few factors that I found valuable to take note of as I venture into reflecting on and establishing how religious experience and specifically meaning-making, is possible in the process of watching films. 
Firstly, the relationship between the ideology of capitalistic culture and popular culture should not be ignored. Lynch (2008:79) notes that these reflections on popular culture could be based on an idealised form of religion or on the reduction of the complexities of lived experiences or even the '....risk of forcing cultural resources and practices into a 'quasireligious' mould which can distort our interpretations of lived cultures'. Similarly, Mcloud (2003:188) concluded after examining a few studies that viewed popular culture as religion, with an alternative interpretation, namely that it is rather the project of the self, seeking for self-identity in context where it is no longer ascribed but achieved. In order to find a balance between the optimistic assertions that popular culture can serve as a form of authentic religion and the pessimistic assumption that it cannot function as a medium of religious experience, it is important to take note of this criticism (Lynch 2008:80). I am not arguing that watching film should be viewed as religion, but rather that film as a form of lived religion has the qualities that could create a religious experience and serve as medium of meaning-making. The religious function of popular fits best within the functionalist view of religion. According to the functionalist view, religion performs certain functions for individuals and society. This function includes a social, existential or hermeneutical and transcendent function. These functions are, however, not considered equally important. In contrast to the functionalist view of religion, the substantive view of religion postulates that religion is characterised by certain elements like supernatural forces; people with specific religious roles like priests, traditions, rituals; and sacred spaces like churches and synagogues (Lynch 2005:27).

\section{Film and religion}

Hackett and Soares (2015:1) describe the interrelatedness between media and religion by stating '... understanding media is vital to understand religion and the history of Christianity in Africa ...' Furthermore, they view film as having an integrative function by being a mediator between local and global; traditional and modern. Similarities between theatre and religion entails the inclusion of play, performance and visuality (Merz 2015:103). To illustrate the relationship between film and religion, I would like to emphasise the way film uses and presents religion. The Bible as sacred text is used more in the media today than before especially in music and film. Punt (2013:1) describes this tendency as popularising of the Bible in the media and refers to the 'pop-bible'. The pop-bible could give a possible platform for discussion. It could, however, also represent a shallow and even twisted interpretation of the sacred texts (Punt 2013:3-5). Movies project and rewrite scripture through a different medium. Screening scripture is an act of translation as the same words could have different meanings in the new medium. It is, however, important to register that film could use religion to make points on religious and non-religious topics or to energise the narrative (Flesher \& Torry 2007). Popular cinema covers spiritual or religious themes like love and death and is to a great extent the reflection of the 'daydreams of society'.
Especially film is described by Herrmann (2003:192) as the religion of society because it 'gives symbolic answers to existential questions'. Film is, therefore, entertainment and simultaneously a source for interpreting the world and meaning-making (Herrmann 2003:190). Film introduces the sacred in the secular in everyday life and is a good example of how spirituality is about our everyday life and a soughtafter agent of meaning-making. That implies that popular culture could replace the role of religious institutions and text as traditional agents of meaning-making. Film and religion are also very complex, but interesting fields of research as they help us to investigate how a seemingly secular act could create a spiritual experience.

Hjarvard (2008:10) argues that religion receives much more attention in the media, be it through film with an explicitly religious theme and message or institutionalised religion like Christianity or Islam through factual programmes. Hjarvard, however, cautions that the visibility of religion through the media is a reflection of the process of mediatisation of religion whereby religious beliefs, symbols and agency are influenced by the media. He argues mediatisation of religion entails that religion is contested and reasserted by the media and in the process undergo a transformation. In another insightful article Hjarvard (2015) argues that the mediatisation of religion through the media makes the media an agent of religious change. He substantiates his argument by illustrating how film makes the supernatural seems natural and how religion features in film.

The media, especially through film, manages to bring back enchantment and therefore an appreciation for the irrational. Hjarvard (2008:16) argues that new religious movements indicate a return to enchanting elements of the pre-modern world. In order to validate his arguments on media and religion, Hjarvard (2008) undertook an empirical study and collected data from people older than 18 years on how the media is a medium for spiritual engagements in their lives. One of the interesting findings is that institutionalised ways of engaging with religion like going to church and reading religious texts, does not have the same spiritual function compared with the use of the media. The media genres that are functioning as sources of moral orientation, are narrative and fictional (Hjarvard 2008:21). Apostolides and Meylahn (2014:3) argue that fantasy as genre of film could be a relevant response to the relevance crisis of the church. Fantasy assists people to imagine an alternative reality and not necessarily to escape reality - rather to make greater contact with reality. Furthermore, fantasy could enable the viewer of film to ask existential questions about life and the meaning thereof (Apostolides \& Meylahn 2014:4). From the vivid overview on film as culture product that forms part of popular culture and lived religion it could be argued that film has religious significance and is, therefore, sources for theological reflection.

\section{Why is theological reflection on film as popular culture important?}

Although religion and theology could be defined as two distinct disciplines, they are also intertwined in significant 
ways. Theology carries a variety of religions within them (Marsh 2007:12). Therefore Marsh (2007:11) argues that there is no theology without religion. Theology derives its subject matter from the practice of religion. Religion, however, does not only include ideas and beliefs, but also works with symbols, rituals, gestures and ethical action. Furthermore, religion exists and functions within culture and is culture itself. Therefore, theological reflection on religion is always contextual. Although theology pays attention to internal authority of religion, it does not simply expound religious ideas, but focuses on teasing out these ideas and beliefs from religious tradition and practices. An important focus is also the interaction of the participants of religion with the wider culture (Marsh 2007:13). The overlap between human activities and religious commitment broadens the field for theology considerable. While there seems to be a decline in institutional religion, other forms of religion are emerging as a source for religious directions and experience. It could, therefore, be argued that popular culture provides a hermeneutical function whereby people can make sense of their experience and life. Theological reflection on film as medium for meaning-making, therefore, examines how Christian theology functions culturally (Marsh 2007:18).

The fact that film mirrors the dreams, fears, hopes and values of society makes it a vital focus for theological reflection. Although watching film is not a form of structured, institutional religion, it has everything to do with religion. Film as a cultural product and watching films could rather be placed under the category of lived religion which refers to what people do in their everyday life that has religious significance. According to Smith (2012:245) '... attention to cultural is one of the defining features of the present moment in practical theology'. This reflection, therefore, confirms the broader scope of practical theology from primarily the ecclesial and clerical paradigm to include everyday activities like watching films.

Theological reflections on film is still in its infancy. However, film became especially the Western culture's major storytelling and myth producing medium (Johnson 2007:15-17). According to Ortiz (2007:73) the most popular film in the beginning of cinema was religious film. Theological reflection on film, especially in the initial stage, focused on the text of film depending on literary models. Film, however, consists of at least three integral components, namely imaginary, narrative and music. Therefore theological reflection needs to encompass all these elements (Taylor 2007:66). A broader scope of theological engagements with film specifically is therefore paramount. The focus should not only be on analysing the content of film, but even more important on who is the viewer and what does the viewer make of the content? There is increasing understanding that the viewer is central to the meaning-making process. The focus on the viewer or the audience means that there is no single prescribed message from the film, but various ways in which the same film could be understood and experienced. 'The theology that emerges from this kind of engagement is not so much a theology of answers as a theology of engagement ...' (Taylor 2007:67).
Practical theology is by nature done from an interdisciplinary perspective and is therefore ideal to reflect on film and meaning-making by the viewers through film. Theology could benefit from drawing on knowledge and expertise from other disciplines, because theologians will have to learn new disciplinary language and concepts (Lynch 2007:109110) Film conveys a message through images, while most theologies, like the Protestants theology, is word-based. Therefore the image-driven society created by film could enhance a word-based theology (Johnson 2007:19). Film is one of the areas that makes the current world one of images and not only of oral and written words. That of course also poses a challenge to theology, Protestant theology specifically, as such theology developed in an era of logic arguments when the written word dominated society. In a world where symbols and experience are very important, a shift towards a more sacramental approach where signs and symbols are important, will be of importance (Detweiler 2007:31-32). Theology should therefore not only be employed to analyse and critique film, but are also challenges by the world film created and how it portrays, rewrite and challenges dogmatic positions and traditions. At the same time '... a film theory focused upon moving images, can enhance a word-bound theology' (Detweiler 2007:33). Taylor (2007:66) notes that theology '... should be prepared to lay aside our objective and sometimes pre-packaged ideas' when engaging with reflection on film.

Nancy Ammerman (2007:4) contends that there is a need to investigate the seemingly paradox of religion being absent and present at the same time in the modern world. Although there seems to be a decline in institutional forms of religion, other forms of being religious and forms of religion seem to be emerging at the same time. She argues that to understand these emerging forms of being religious, the everyday lives of people need to be observed and reflected on. In this form of investigation, the experience of non-experts is of great value. Ammerman (2007:5) explains that this does not mean that official ideas on religion do not matter, but that they become more interesting when used by people in everyday living. Everyday religion she contends, happening in private and public life, includes privileges and non-privileges. Questions that will guide such investigation also relevant for this article are: 'When and where do we find experiences that participants define as religious or spiritual? Where do we find symbols and assumptions that have spiritual dimensions, even if they are not overtly defined as such?' (Ammerman 2007:5). Theological reflections on such every day and seemingly not religious actions are necessary because theology is not only a static body of knowledge. It involves a dynamic process of reflection that explores traditional theological resources in the light of contemporary questions, beliefs and practices (Lynch 2008:96). Both Lynch (2008:73) and Marsh (2007:18) also argue that, although there seems to be a decline in institutionalised forms of religion, the need to reflect on popular culture as a possible source for religious experience becomes paramount. Marsh (2007:18) argues in such a context it will be important to explore how Christianity functions culturally. Furthermore, the realms of religion and 
media can no longer be separated, but in many ways, they are occupying the same space. This implies that religious practices and beliefs are intertwined with the cultural products of which they are part of. Moreover, people that do not profess a religious tradition, engage with meaningmaking in similar ways than those that do. The difference, however, is the identity of the resources accessed and used in the process of meaning-making (Marsh 2007:18).

Lynch (2005:22-23) also identified a few very important reasons why theological engagement and reflections on popular culture are important. Firstly, he suggests that religion is portrayed and represented in different ways by the media, while religion also makes use of the media. Secondly, popular culture could assist theologians and religious scholars to understand the nature of contemporary society, as well as how cultural resources can help us to live good and meaningful lives. Furthermore, popular culture shapes the beliefs and practices of religious groups. Lastly, it is important for theologians to understand how religious groups engage with the wider culture.

Theological reflections on popular culture also imply that theologians accept the religious significance thereof and do research beyond the boundaries of the Church or religious institutions (Lynch 2005:30). Lynch (2008:72) contends that theological reflections on popular culture provides an analytical discussion on the nature and structure of religious experience and a normative discussion on how the sacred may be present and cultivated through contemporary culture.

Theological reflection on popular culture is therefore potentially rewarding as it allows reflection that is grounded in cultural resources and challenges of contemporary society. Films is an important medium for the transmission of culture, of which values and meanings is an important part and of specific interest for theological reflection (Lynch 2007:110). It also, has the potential to facilitate interaction between theory and empirical data and generates significant insights about the understanding of religion. Moreover, such reflection could also indicate how religion and the sacred persist and evolve in contemporary society (Lynch 2008:83). In this reflection the religious and theological value of popular culture are acknowledged and suggested that, although theology should comment on cultural, it should at the same time be conscious of the fact that theology and religious practices are embedded in culture.

Therefore, theology should rather be in critical dialogue with culture acknowledging the presence of God beyond the church. This approach of critical dialogue between theology and culture is also grounded in the belief that humans are created in the image of God and therefore also co-creators of what God wants for this world. The creative aspects of human beings as co-creators are therefore acknowledged and appreciated (Marsh 1997:29). Theological reflection on film and their possible religious significance appreciates not only the cognitive aspects of being human, but also pays attention to the emotional and aesthetic aspects of human life
(Marsh 1997:33). Moreover, film creates an experience that broadens and questions our worldview. It is not only about having a good time - although that is what most people have in mind when watching films - but also challenges how we live our lives. The focus on emotion that is a key part of experience, is also an important part of meaning-making. Although the cognitive dimension is often emphasised in theology, feelings and experience, it increasingly plays an important role in peoples' lives in general and in religious life specifically.

Investigating religion beyond religious pews, however, poses methodological challenges and '... will require that we measure in more subtle and creative ways' (Davie 2007:27). Lynch (2005:106) suggests that a revised correlation approach also takes serious praxis model. Through such an approach both popular culture and theology are each taken seriously on their own terms. In other words, each conversation partner is taken seriously and could contribute in seeking the truth and meaningful living. Having popular culture as a critical conversational partner could assist theology to be contextual as popular culture could be viewed as a window of the issues of the day. You cannot count everyday religion and therefore qualitative methods as the best way of investigation. Lynch (2005) proposes specific ethnographic studies as method of studying, implying a turn to the audience, voicing their experience and what it means to them. The value of a cultural text like a film, however, is not necessarily determined by the aesthetic quality thereof, but rather by the lived experience of the person (Lynch 2008:76). Babie et al. (2007:279) describe the ethnography as the work of describing culture. It is not so much focusing on studying people, but rather on learning from people. As practical theology is concerned with what people do, why they do it and what are the implications for their faith, reflections on the religious significance of film for viewers, fits very well within the discipline. Such reflections on everyday actions like film-watching assist theology to meet people where they are and their experiences and practices that form part of their world. Furthermore, it strengthens and enhances the interdisciplinary nature of practical theology as such research will not be possible without other disciplines like culture and media studies Pattison 2009:56).

\section{Conclusion}

This article points out the religious significance of watching films as part of popular culture. It is argued that there is a need for theological reflection on everyday actions and experiences like watching films as part of lived religion. Such reflections become paramount in a context where institutionalised forms of religion seem to be on the decline. Practical theological reflection on popular culture could also be beneficial to theology as it broadens the scope of theological reflection from the clerical paradigm to include everyday activities like watching film. Furthermore, empirical investigation that takes the lived experience of people seriously could help us to identify changed forms of religion as part of everyday living. 


\section{Acknowledgements Competing interests}

The author declares that he has no financial or personal relationships which may have inappropriately influenced him in writing this article.

\section{References}

Ammerman, N. (ed.), 2007, Everyday religion: Observing modern religious lives, University Press, Oxford.

Apostolides, A. \& Meylahn, J., 2014, 'The lived theology of the Harry Potter series', HTS Theological Studies 70(1), 1-6. https://doi.org/10.4102/hts.v70i1.2713

Babie, E., Mouton, J., Voster, P. \& Prozesky, B., 2007, The practice of social research, Cape Town, ABC Press.

Browne, D., 1997, 'Film, movies and meanings', in C. Marsh \& G. Ortiz (eds.) Explorations in theology and film: Movies and meaning, pp. 9-20, Blackwell Publishers, Oxford.

Corrigan, T. \& White, P., 2004, The film experience: An introduction, Bedford/ST. Martin's, Boston, MA.

Davie, G., 2007, 'Vicarious religion: A methodological challenge', in N. Ammerman (ed.), Everyday religion: Observing modern religious lives, pp. 21-36, University Press, Oxford.

Detweiler, C., 2007, 'Seeing and believing', in R.K. Johnson (ed.), Reframing theology and film: New focus for and emerging discipline, pp. 29-50, Baker Academic, Grand Rapids, Ml.

Fiske, J., 1989. Understanding popular culture, Unwin Hyman, London.

Flesher, P.V.M., \& Torry, R., 2007, Film \& religion, Abingdon Press, Nashville, TN.

Ganzevoort, R., 2011, 'The public significance of religion', in L.J. Francis \& H.-G. Ziebertz (eds.), Framing the gods. The public significance of religion from a cultural point of view, pp. 95-120, Brill, Leiden.

Ganzevoort, R., 2015, 'Silence speaks. Theological musings on silence in religion and film', in F.L. Bakker, M. Van Dijk, L. Van der Tuin \& M. Verbeek (eds.), Blessed are the eyes that catch divine whispering. Silence and religion in film, pp. 123-137, Shüren, Marburg.

Ganzevoort, R. \& Roeland, J., 2014, 'Lived religion: The praxis of practical theology', International Journal of Practical theology 18(1), 91-101. https://doi.org/10.1515/ ijpt-2014-0007

Hackett, R.IJ. \& Soares, B.F., 2015, 'Introduction: New media and religious transformations in Africa', in R.I.J. Hackett \& B.F. Soares, New media and religious transformations in Africa, pp. 1-10, Indiana University Press, Bloomington, IN.

Hall, S., 1981, 'Notes on deconstructing the "popular"', in R. Samuel (ed.), People's history and social theory, pp. 227-240, RKP, London.
Herrmann, J., 2003, 'From popular to arthouse: An analysis of love and nature as religious motifs in recent cinema', in J. Mitchell \& S. Marriage (eds.), Mediated religion: Conversations in media, religion and culture, pp. 180-189, T\&T Clark Ltd religion:
London.

Hjarvard, S., 2008, 'The mediatisation of religion: A theory of the media as agents of religious change', Northern Lights Volume 6(9-25), 9-19.

Hjarvard, S., 2015, 'Mediation and the changing authority of religion', Media, Culture and Society 38(1), 8-17. https://doi.org/10.1177/0163443715615412

Johnson, R.K., 2007, 'Introduction: Reframing the discussion', in R.K. Johnson (ed.), Reframing theology and film: New focus for and emerging discipline, pp. 15-28, Baker Academic, Grand Rapids, MI.

Lynch, G., 2005, Understanding theology and popular culture, Blackwell Publishing, Victoria.

Lynch, G., 2007, 'Film and the subjective turn: How the sociology of religion can contribute to theological readings of film', in R.K. Johnson (ed.), Reframing theology and film, pp. 109-125, Baker Academic, MI.

Lynch, G., 2008, 'Religious experience and popular Culture', in H. Zock (ed.), At the cross roads of art and religion, pp. 71-83, Peeters, Leuven.

Marsh, C., 1997, 'Film and theologies of culture', in C. Marsh \& G. Ortiz (eds.) Explorations in theology and film: Movies and meanings, pp. 24-34, Blackwell Publishers, Oxford.

Marsh, C., 2007, Theology goes to the movies: An introduction to critical Christian thinking, Routledge, London.

Mcloud, S., 2003, 'Popular culture fandoms, the boundaries of religious studies and the project of the self', Culture and Religion 4(2), 187-206. https://doi.org/10. 1080/01438830032000135674

Merz, J., 2015, 'Mediating transcendence: Popular film, visuality and religious experience in West Africa', in R.I.J. Hackett \& B.F. Soares, New media and religious transformations in Africa, Indiana University Press, Bloomington, IN.

Ortiz, G.W., 2007, 'World cinema: Opportunities for dialogue with religion and theology', in R.K. Johnson (ed.), Reframing theology and film: New focus for and emerging discipline, pp. 73-87, Baker Academic, Grand Rapids, MI.

Pattison, S., 2009, 'Deepening relationships with material artefacts', in C. Deacy \& E. Arweck (eds.), Exploring religion and the sacred in a media age, pp. 54-69, Ashgate Publishing Company, Burlington, VT.

Priner, M.L., 2009, 'Religious socialization by the media? An empirical study and conclusion for practical theology', International Journal of Practical Theology 13 275-292.

Punt, J., 2013, 'Die pop-Bybel vandag', Nederduitse Gereformeerde Teologiese Tydskrif 54(1\&2), 1-12. https://doi.org/10.5952/54-1-2-315

Smith, T.A., 2012, 'Theories of practice', in B.J. Miller-McLemore (ed.), The WileyBlackwell companion to practical theology, pp. 244-254, Wiley-Blackwell, Oxford.

Taylor, B., 2007, 'The colours of sound: Music and meaning making in film', in R.K. Johnson (ed.), Reframing theology and film: New focus for and emerging discipline, pp. 51-69, Baker Academic, Grand Rapids, MI. 